\title{
Serendipitetsfaktorer og brugeradfærd på det fysiske bibliotek
}

\section{Af Lennart Björneborn}

\begin{abstract}
I en eksplorativ undersøgelse blev der gennem 10 måneder $i 2006$ observeret og interviewet biblioteksbrugere på Københavns Hovedbibliotek og det nybyggede filialbibliotek $i$ Vanløse. De to folkebiblioteker blev valgt for at supplere hinanden i relation til størrelse, indretning og brugersammenscetning. De to overordnede forskningsspørgsmål $i$ undersøgelsen var, hvilke typer informationsadfcerd brugere benytter sig af til at finde materialer i fysiske biblioteksrum, samt hvilke faktorer i fysiske biblioteksrum, der kan påvirke muligheder for serendipitet, dvs. uplanlagte fund. Det overordnede formål med undersøgelsen var at udvikle modeller for samspillet mellem brugeres informationsadfcerd og bibliotekets fysiske 'brugergraenseflader'.
\end{abstract}

Ud fra observationer, interviews og tonke-højt-sessioner med brugere blev der lavet en model for, hvordan brugere finder materialer ved forskellige kombinationer af konvergent (målrettet) adfoerd og divergent (eksplorativ) adfcerd. Undersøgelsen viser, hvor sammensat og situationelt betinget brugernes hverdagspraksis kan vare i biblioteket, og hvordan konvergent og divergent brugeradfcerd kan påvirke og afløse hinanden ved samme biblioteksbesøg. Brugernes hverdagspraksis indbefatter bl.a. forskellige former for cross-over-adfcerd og indirekte bruger-

Lennart Björneborn er lektor, ph.d. ved Danmarks Biblioteksskole,lb@db.dk til-bruger-formidling. Identificerede serendipitetsfaktorer i det fysiske bibliotek inkluderer uhindret adgang, diversitet, eksponering, kontraster, markører, uperfekte sprakker, krydskontakter, 'multi-reachability' (mange adgangsveje), 'explorability' og 'stopability'.

På basis af undersøgelsen blev der udviklet en model for biblioteket som samlet brugergrcenseflade bestående af alle kontaktflader mellem brugere og bibliotekets menneskelige, fysiske og digitale informationsressourcer og formidlingsveje. I artiklen peges på, hvordan bibliotekets formidlingspolitik kan sammentoenke formidlingsveje mellem forskellige informationsressourcer i biblioteket, så de supplerer hinanden og understøtter 'affordances' (brugspotentialer) for både konvergent og divergent brugeradfcerd, bl.a. ved at understøtte serendipitetsfaktorer i biblioteket.

\section{Indledning}

Biblioteksdebatten, der blev udløst af et interview med Københavns Hovedbiblioteks nye chef Pernille Schaltz i Politiken (Andersen, 2007), har dybest set kredset om tre centrale aspekter vedrørende folkebibliotekers (især fysiske) berettigelse:

- Hvad er et bibliotek? Hvad kan et bibliotek? Hvad skal et bibliotek?

Undersøgelsen, der præsenteres i nærværende artikel, er et bidrag til at kvalificere debatten vedrørende disse tre aspekter ved at se nærmere på, hvordan 
brugere interagerer med fysiske biblioteker, herunder hvordan deres adfærd er og hvilke muligheder for uplanlagte fund ('serendipitet'), biblioteket tilbyder dem.

Hvor forskning i biblioteks- og informationsvidenskab i flere år har fokuseret på samspillet mellem brugere og bibliotekets digitale brugergrænseflader, er det overordnede formål med nærværende undersøgelse at blive klogere på - og udvikle modeller for - samspillet mellem brugernes informationsadfærd og bibliotekets fysiske 'brugergrænseflader'.

Brugeres informationsadfærd i fysiske folkebiblioteker er blevet undersøgt på forskellig vis gennem de sidste årtier. Der har været omfattende undersøgelser af græsning ('browsing') i folkebiblioteker ( $\mathrm{fx}$ Goodall, 1989) og social aktivitet i folkebiblioteker inklusive informationsadfærd (fx Given \& Leckie, 2003; Leckie \& Given, 2005). Der er desuden stigende opmærksomhed på, hvordan indretning, design og brugervenlighed kan forbedres i fysiske biblioteker (fx Lushington, 2002; Buschman \& Leckie, 2007; Niegaard et al., 2008).

Ifølge to centrale forskere på området, Leckie \& Given (2005), mangler der stadig viden om, hvordan brugeres informationsadfærd er i fysiske biblioteker. Her kan tilføjes, at der måske især mangler undersøgelser, der afdækker muligheder for serendipitet på biblioteker, hvor brugere finder materialer og informationer, de ikke målrettet har ledt efter. ${ }^{1}$

På denne baggrund var de to overordnede forskningsspørgsmål i den eksplorative undersøgelse, der præsenteres i denne artikel²:

1. Hvilke typer af informationsadfærd benytter brugere til at finde materialer på folkebiblioteker?

2. Hvilke faktorer i fysiske biblioteksrum påvirker muligheder for serendipitet?

\section{Metode}

To folkebiblioteker, Københavns Hovedbibliotek og det nybyggede filialbibliotek i Vanløse, blev udvalgt som cases i undersøgelsen. De to biblioteker blev valgt for at supplere hinanden i relation til størrelse, indretning og brugersammensætning.
Hovedbiblioteket (herefter: HB) i Krystalgade i København er centralt beliggende i Middelalderbyen og i gåafstand fra S-togsstation og metro. Biblioteket har til huse i et tidligere møbelvarehus med rulletrapper, der forbinder de fem etager. Karakteristisk for besøgende på HB er ifølge kommunens biblioteksundersøgelse fra 2004 (KKB, 2004), at flere brugere er under uddannelse og færre er i arbejde end gennemsnittet for Københavns biblioteker. I 2006 havde HB ca. 760.000 besøgende (ca. 2500 pr. åbningsdag) og et udlån på ca. 1,2 mio. materialer.

Det nye Vanløse Bibliotek (herefter: VB) ligger i et forstadsområde i Københavns kommune og blev indviet i efteråret 2005. Det er bygget sammen med Kulturhuset og placeret centralt ved S-togsstation og metro. Biblioteket består af et stort lyst rum inddelt i zoner omkring et centralt Torv. Karakteristisk for besøgende på VB er ifølge kommunens biblioteksundersøgelse fra 2004 (KKB, 2004), at der er en større andel $i$ arbejde og en større andel af kvinder end gennemsnittet for Københavns biblioteker. I 2006 havde VB ca. 220.000 besøgende (ca. 700 pr. åbningsdag) og et udlån på ca. 300.000 materialer.

I den eksplorative undersøgelse foretaget af forfatteren og en kultursociolog blev der gennem en 10 måneders periode i 2006 observeret og interviewet biblioteksbrugere på de to case-biblioteker. Der blev $i$ alt interviewet 113 brugere (HB 73 og VB 40). 118 brugere blev anmodet om interview, men 5 afslog. Udvælgelse af brugere til interviews skete med spredning på køn og alder (over 15 år) og foregik på forskellige ugedage og tidspunkter i en 10 måneders periode. Brugerne blev anmodet om en kort samtale om deres bibliotekspraksis, mens de var i færd med at lede efter eller låne materialer (jf. interviewguide, Bilag 1). Ca. $10 \%$ af interviewpersonerne (HB 7 og VB 4) gik sammen med en forsker rundt $i$ biblioteket i en tænke-højt-session, hvor de blev bedt om at komme med kommentarer og refleksioner om, hvad der triggede deres opmærksomhed og informationsadfærd. Udover interviews blev brugere observeret, dels i tilknytning til interviews og dels ved observationer af specifikke destinationer, 'sweeps' (hurtige her-og-nu-optællinger, jf. Given \& Leckie, 2003) af hele afdelinger og trafiktællinger på de to biblioteker. Data fra observationer, interviews og tænke-højt-sessioner blev transskriberet og analyseret i en iterativ process med kategoriseringer og kondenseringer. 
De brugte metoder er inspireret af forskning om brugeradfærd og social aktivitet på folkebiblioteker (Given \& Leckie, 2003) og kundeadfærd i shoppingforskning (Underhill, 1999). Det er vigtigt at understrege, at undersøgelsen ikke har haft til hensigt at komme med generaliserbare resultater, men på eksplorerende vis at identificere fænomener og generere hypoteser i relation til serendipitetsfaktorer og brugeradfærd på det fysiske bibliotek.

\section{Resultater og diskussion}

Udvalgte resultater fra undersøgelsen præsenteres og diskuteres i de følgende fire underafsnit. Første afsnit præsenterer en model med forskellige måder at finde materialer på, hvor brugerne kombinerer forskellige former for konvergent (målrettet) og divergent (eksplorativ) informationsadfærd. I denne forbindelse beskrives også brugerens interessesfcere ('interest space'). Næste afsnit gennemgår brugernes komplekse hverdagspraksis, herunder aspekter i relation til selvforhandlinger ('skal/skal ikke'), cross-overadfærd, bruger-til-bruger-formidling og brugernes kropslighed. For at sætte brugernes informationsad- færd ind i en større kontekst, præsenterer tredje afsnit en model for biblioteket som samlet brugergrænseflade. Sidste afsnit før konklusionen fremlægger 10 identificerede serendipitetsfaktorer i det fysiske bibliotek.

\section{Konvergent og divergent informationsadfærd}

Undersøgelsen tegner et mønster, hvor interviewede brugere med egne ord skelner mellem "målrettet" søgning af materialer til brug i arbejde, studier, hobbies mm. og "fornøjelig" og "lystbetonet" græsning af materialer til inspiration, oplevelser og afslapning.

I undersøgelsens model- og begrebsudvikling bruges betegnelserne konvergent og divergent for at beskrive og diskutere ovennævnte to hovedtyper af informationsadfærd hos brugere: konvergent, målrettet adfærd og divergent, eksplorativ adfærd, jf. Tabel 1. Termerne er inspireret af en diskussion hos Ford (1999) om brugernes behov for både konvergent og divergent 'information processing' i IR-systemer ('Information Retrieval', dvs. informationsgenfinding).

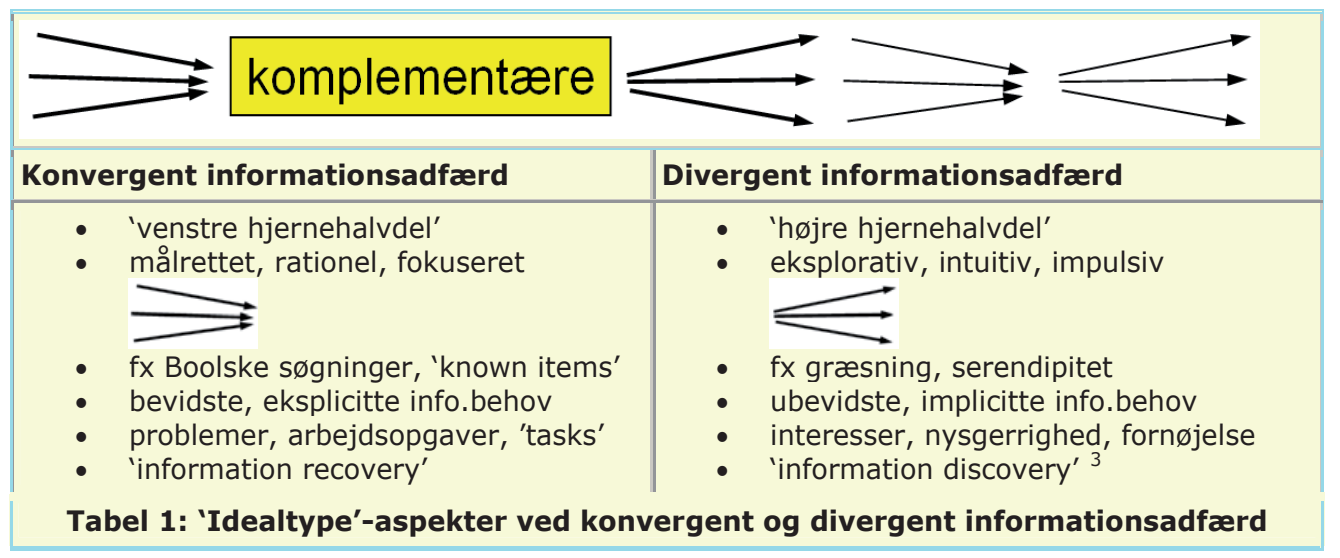

Tabel 1 viser en dikotomisk opdeling af anskueliggørende 'idealtype'-aspekter ved konvergent og divergent informationsadfærd. Konvergent informationsadfærd er målrettet, rationel og fokuseret ('venstre hjernehalvdel'), fx ved brug af Boolske søgestrenge ('AND', 'OR', mm.) i databaser efter kendte titler og forfattere ('known items'). Denne adfærd kan tilgodese bevidste, eksplicitte informationsbehov, der udspringer af specifikke problemer, arbejdsopgaver ('tasks'), mm.
Divergent informationsadfærd derimod er mere eksplorativ, intuitiv og impulsiv ('højre hjernehalvdel'), fx når brugere afsøger et fysisk eller digitalt informationsrum for at se, hvad det indeholder af potentielt interessante ting. Dette kan lede til uplanlagte, serendipitive materialefund $\mathrm{fx}$ ved at græsse ved biblioteksreoler. Denne adfærd kan tilgodese mere ubevidste, implicitte og 'mudrede' (Ingwersen, 1992) informationsbehov, der bl.a. kan udspringe af nysgerrighed, lyst til adspredelse eller brugerens hele mangfoldighed af store og små interesser, dvs. hele 
brugerens 'interest space' eller interessesfære som beskrevet i næste afsnit.

I biblioteksbrugernes hverdagspraksis blandes de to adfærdstyper med hinanden på komplementær vis, som antydet med den bølgende 'adfærds-puls' øverst i Tabel 1. For eksempel viste undersøgelsen, hvordan konvergent, målrettet adfærd kan bruges til at identificere materialer eller informationer, der senere kan fungere som udgangspunkt for mere divergent, eksplorativ adfærd. Flere interviewpersoner søgte således målrettet hjemmefra i bibliotekets webkatalog, og når de senere stod ved bibliotekshylden, brugte de muligheden for at udforske omkringliggende hylder. Det digitale og fysiske biblioteksrum supplerer her hinanden. Med Garfield (1984) kan man tale om, at der skabes muligheder for både 'information recovery' og 'information discovery' - en kombination han prioriterer i informationssystemer (jf. fodnote 3).

\section{Brugerens interessesfore}

Det, der her kaldes brugerens 'interessesfære', ('interest space') er simplificeret illustreret i Figur 1 ved et 'isbjerg' i brugerens hoved. I denne interessesfære findes ('oven vande') en lille del bevidste informationsbehov og interesser (A) og ('under overfladen') en stor del ubevidste interesser (B-D). Disse 'latente' interesser, der kan være både store og små, kan trigges (fx ved brugerens perifere syn), når brugeren bevæger sig gennem et informationsrum (fysisk/digitalt bibliotek, nettet, storby, mv.) og møder dette rums brugspotentialer.

I 'affordance'-teori (Norman, 1999; Sadler \& Given, 2007) svarer 'affordances' til de brugspotentialer og handlemuligheder, som et fysisk eller digitalt informationsrums indretning og design tilbyder ('afford') brugere i relation til adfærd, brug og oplevelser. Biblioteker skaber bl.a. 'affordances' (herefter: brugspotentialer) ved at eksponere materialer på en indbydende måde. I Figur 1 søger brugeren konvergent, målrettet efter et materiale (A), men informationsrummets brugspotentialer kan lokke brugeren ud på divergente eksplorationer af eksponerede materialer (B-D), der trigger brugerens interessesfære ved at skabe nysgerrighed, genkendelse, $\mathrm{mm}$.

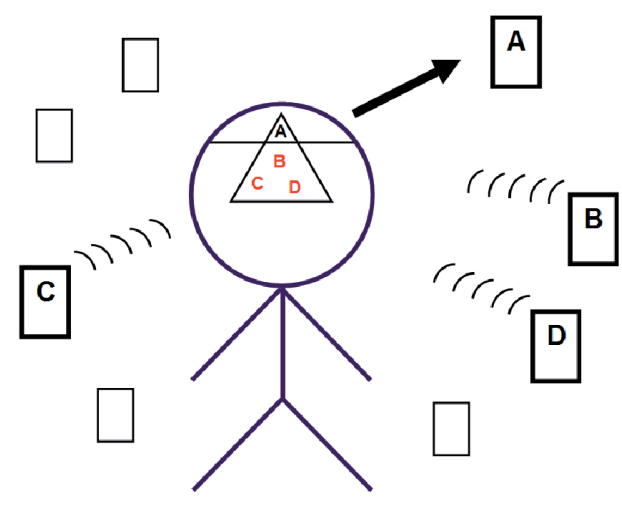

Figur 1. Brugeren på vej gennem et informationsrum søger efter materiale A og møder potentielt triggende materialer $B, C, D$, der matcher brugerens interessesfore ('interest space') symboliseret ved 'isbjerget' $i$ brugerens hoved.

\section{Typologi for materialefund}

Figur 2 og Tabel 2 viser identificerede typer af materialefund i undersøgelsen ved hjælp af forskellige kombinationer af konvergent og divergent informationsadfærd. Typologien er inspireret af Windings (2007a; 2007b) kategorier af lånertyper ${ }^{4}$. I nærværende undersøgelse blev typologien videreudviklet for at dække blandingsformer mellem måderne, som brugerne finder materialer på. Typologien fokuserer derved på variationen i selve adfærden frem for at søge at placere brugere i faste kategorier. Det giver således mere mening at tale om 'brugstyper' end om 'brugertyper', da brugstyperne er situationelt betingede og kan skifte fra biblioteksbesøg til biblioteksbesøg, hvilket uddybes i et efterfølgende afsnit.

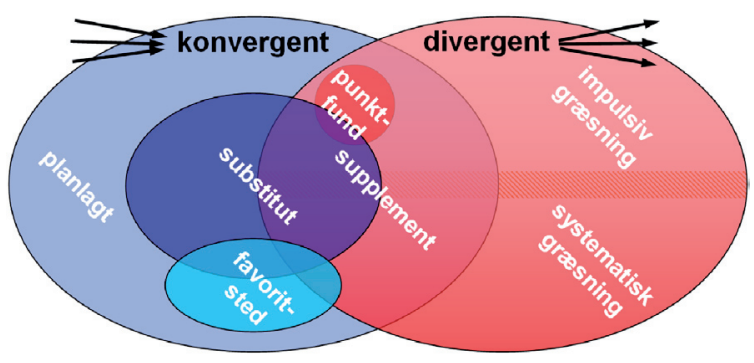

Figur 2. Identificerede typer af biblioteksbrugeres materialefund ved hjcelp af konvergent og divergent informationsadfcerd. Se forklaring i Tabel 2.

De forskellige materialefundstyper illustreret i figuren fordeler sig som angivet i Tabel 2. 


\begin{tabular}{|c|c|}
\hline Materialefundstyper & Forklaring \\
\hline Planlagte fund & $\begin{array}{l}\text { Brugere finder, hvad de har planlagt at finde ('known item') ved } \\
\text { konvergent mălrettet adfærd. }\end{array}$ \\
\hline Favoritstedfund & $\begin{array}{l}\text { Nogle målrettede brugere opsøger samme få favoritsteder for at } \\
\text { finde materialer, hver gang de besøger biblioteket. }\end{array}$ \\
\hline Substitutfund & $\begin{array}{l}\text { Brugere, der finder ikke planlagte materialer, kan erstatte dem } \\
\text { med lignende materialer som substitut. }\end{array}$ \\
\hline Supplementfund & $\begin{array}{l}\text { Brugere kan supplere planlagte fund og substitutfund med } \\
\text { materialer fundet gennem forskellige former for græsning. }\end{array}$ \\
\hline Systematisk græsning & $\begin{array}{l}\text { Brugere finder materialer ved systematisk at bevæge sig gennem } \\
\text { biblioteksrum og skanne eksponerede materialer. }\end{array}$ \\
\hline Impulsiv græsning & $\begin{array}{l}\text { Brugere finder materialer ved usystematisk og impulsstyret } \\
\text { adfærd. }\end{array}$ \\
\hline Punktfund & $\begin{array}{l}\text { Enkeltstående punktfund ('incidental encounter'), hvor brugeren } \\
\text { undervejs finder uplanlagt men interessant materiale. }\end{array}$ \\
\hline \multicolumn{2}{|c|}{$\begin{array}{c}\text { Tabel 2: Identificerede typer af biblioteksbrugeres materialefund ved hjælp af } \\
\text { konvergent og divergent informationsadfærd }\end{array}$} \\
\hline
\end{tabular}

Mange brugere benytter således rent konvergent adfærd, hvor de finder lige det, de har planlagt. Nogle målrettede brugere opsøger de samme få favoritsteder, fx krimier eller filosofibøger, hver gang de besøger biblioteket. Nogle gange finder brugerne ikke de planlagte materialer, der så erstattes med lignende materialer som substitut. For eksempel svarer figurens overlap mellem de to felter 'favoritsted' og 'substitut' til favoritstedbrugere, der laver et målrettet substitutfund, når det ønskede materiale ikke kan findes.

Både planlagte fund, favoritstedfund og substitutfund kan udvides med supplementfund, når brugeren finder noget serendipitivt, uplanlagt ved divergent, eksplorativ adfærd. Undersøgelsen er her i overensstemmelse med tidligere forskning på området med påvisning af flere typer græsning (fx Chang \& Rice, 1993; Pors 1994). De to typer græsning i Figur 2 og Tabel 2 skal derfor ses som to yderpunkter på et kontinuum med mellemliggende græsningstyper, som indikeret med den uskarpe overgang mellem de to typer i Figur 2. I den ene ende af skalaen befinder sig den overvejende systematiske græsning, hvor brugeren systematisk bevæger sig op og ned langs reoler mm. og lader sig eksponere for, hvad biblioteket har at tilbyde. I den anden ende af skalaen er den impulsive og intuitive græsning, der foregår mere usystematisk og 'sommerfugle'-agtigt med sporadiske nedslag på materialer. En undergruppe er her det enkeltstående punktfund, hvor brugeren i farten oplever serendipitet, dvs. opdager et uplanlagt men interessant materiale.
Tabel 3 viser fordelingen af, hvordan de 113 interviewede brugere i undersøgelsen fandt materialer den dag, de blev interviewet. Blandt de interviewede brugere på Københavns Hovedbibliotek udgjorde de rent konvergente, målrettede materialefund $51 \%$, supplementfund $40 \%$ og de rent divergente, eksplorative materialefund $10 \%$. Tilsvarende tal for interviewpersonerne på Vanløse Bibliotek var 48\%, 40\% og $12 \%$. Der var således næsten samme fordelingstal begge steder, idet ca. 50\% af interviewpersonerne kun havde målrettede materialefund den pågældende dag, mens de resterende ca. 50\% (ca. 40\% supplement og ca. 10\% rent divergent) gav plads til uplanlagte fund.

\begin{tabular}{|c|c|c|c|c|}
\hline Materialefund & HB & $\begin{array}{r}\% \\
(n=73)\end{array}$ & VB & $\begin{array}{r}\% \\
(n=40)\end{array}$ \\
\hline Kun konvergent & 37 & 50.7 & 19 & 47.5 \\
\hline - inkl. planlagt & (23) & $(31.5)$ & (10) & $(25.0)$ \\
\hline - inkl. favoritsted & (10) & $(13.7)$ & (4) & $(10.0)$ \\
\hline - inkl. substitut & (4) & $(5.5)$ & (5) & (12.5) \\
\hline Supplement & 29 & 39.7 & 16 & 40.0 \\
\hline - inkl. planlagt & $(25)$ & $(34.2)$ & $(13)$ & (32.5) \\
\hline - inkl. favoritsted & (1) & (1.4) & (0) & $(0.0)$ \\
\hline - inkl. substitut & (3) & (4.1) & (3) & $(7.5)$ \\
\hline \multirow[t]{2}{*}{ Kun divergent } & 7 & 9.6 & 5 & 12.5 \\
\hline & 73 & & 40 & \\
\hline \multicolumn{5}{|c|}{$\begin{array}{l}\text { Tabel 3: Fordeling af, hvordan } 113 \\
\text { interviewede brugere ved Københavns } \\
\text { Hovedbibliotek (HB) og Vanløse Bibliotek } \\
\text { (VB) fandt materialer i undersøgelsen. }\end{array}$} \\
\hline
\end{tabular}


Som tidligere anført i metodeafsnittet kan resultaterne i undersøgelsen ikke generaliseres, da der er tale om en eksplorativ undersøgelse og ikke en randomiseret stikprøveundersøgelse. Det kunne imidlertid være interessant at efterprøve disse forhold i en større repræsentativ undersøgelse.

Imidlertid kan tallene i undersøgelsen indikere, at en stor del af biblioteksbrugerne er åbne for uplanlagte fund, hvilket bibliotekerne med fordel kan indtænke i deres indretning og formidling.

\section{Kompleks hverdagspraksis}

Som allerede beskrevet, viste brugernes hverdagspraksis sig at være kompleks i relation til at finde materialer på biblioteket. Brugernes adfærd kan således være forskellig fra biblioteksbesøg til biblioteksbesøg og være situationelt betinget af store og små livsomstændigheder, både de skelsættende som fx arbejdsløshed, skilsmisser og barnefødsler, og de hverdagsnære som $\mathrm{fx}$ ferie, regnvejr, fortravlethed og træthed.

I undersøgelsen fandt vi brugere, der har en varieret brug af hele biblioteket, $\mathrm{fx}$ ved at finde materialer $\mathrm{i}$ flere afdelinger og ved på stedet at bruge flere af bibliotekets ydelser. Vi fandt også brugere, der har en varieret brug af flere biblioteker afhængig af, hvilke emner, materialer og services forskellige biblioteker kan tilbyde.

Brugere kan desuden kombinere forskellige typer adfærd under samme biblioteksbesøg. Rækkefølgen mellem konvergent og divergent adfærd kan således ændres undervejs (jf. den bølgende 'adfærds-puls' øverst i Tabel 1), og det uplanlagte fund kan lede til målrettet adfærd.

Et eksempel er en bruger på HB, der tilfældig fandt et fejlplaceret nodehefte med Bette Midler, da han ledte efter noder af Bent Fabricius-Bjerre. Brugeren, der var musiklærer, fik herigennem en idé til i sin undervisning at benytte musik af Bette Midler og søgte derefter målrettet efter cd'ere med den serendipitivt fundne musiker.

Brugere, der bevæger sig gennem biblioteket, kan som beskrevet ændre retning og adfærd, alt eftersom deres store eller små interesser trigges af ting, de møder på deres vej, jf. Figur 1. Dette resultat er relateret til forskning om 'multi-tasking' adfærd og 'information task switching' (Spink, 2004), hvor brugere kan forfølge mange søgeopgaver på én gang og løbende skifte fokus. Denne informationsadfærd er også beskrevet hos Bates (1989) i hendes 'berrypicking'-model, hvor informationssøgning kan være en 'bit-at-a-time'-aktivitet svarende til at finde buske med gode bær, der dukker op efterhånden, som man går gennem skoven.

I relation til undersøgelsens opdeling i konvergent og divergent informationsadfærd kan man se paralleller til shoppingadfærd, hvor den nødvendige shopping af varer til den daglige husholdning kan veksle med den behagelige shopping i form af lyst- og impulsbetingede varekøb (Underhill, 1999). Her kan tilføjes, at biblioteket jo er et frirum fra købetvang og et mulighedsrum, hvor brugeren gratis kan eksperimentere med sin identitet, for eksempel når man overvejer at udvide sin emnehorisont, hvor det ikke koster noget at tage fejl, når man giver nye emner og materialer en chance.

\section{Selvforhandlinger: skal/skal ikke}

Græsning kan give problemer med alle dens valgmuligheder, hvor det kan være svært at vælge. Observationer af brugeres adfærd på de to undersøgte biblioteker gav således indimellem indtryk af at være langvarige selvforhandlinger om lån/ikke-lån af et materiale. Eksempelvis blev en 40-årig mand på VB observeret ved den samme bog på bibliotekets Torv på tre forskellige tidspunkter ved samme biblioteksbesøg. Mellem hvert 'bog-besøg' besøgte han også sektionen med film, cd og udstillede bøger på en bogkarrusel. Ved hvert af de tre 'bog-besøg' tog han bogen op, læste bagsiden, titelbladet og inde i bogen. Han endte op med ikke at låne bogen. Lignende selvforhandlinger om 'skal/skal ikke' er beskrevet i shoppingforskning (Underhill, 1999), hvor kunden kan gå til og fra en stand med varer, berøre varen, tage den op, lægge den igen, fjerne sig fra standen og foretage sig noget andet for igen at komme tilbage til samme stand og afgøre med sig selv, om det skal være et køb eller ej. Underhill (ibid.) anfører, at jo længere tid kunden i boghandlen står med bogen i hånden, jo mindre sandsynlighed er der for køb. Dette gælder også manden i ovenstående eksempel.

I denne forbindelse er det interessant, at der i undersøgelsen nogle gange var uoverensstemmelse mellem observeret adfærd og hvordan observander 
selv beskrev denne adfærd, når de efterfølgende blev interviewet. Enten huskede personerne ikke detaljer mht. hvad de havde foretaget sig, eller de fortalte om deres adfærd på en måde, så den fremstod i et positivt lys. For eksempel observerede vi en person, der var tydelig usikker i sin søgeadfærd ved bogreolerne, men som i det efterfølgende interview sagde, at det lånte materiale var "let at finde".

\section{Cross-over-adferd og opfattede brugspotentialer} I undersøgelsen blev der observeret og interviewet cross-over-brugere, der udnytter og udvider tidligere omtalte 'affordances', dvs. brugspotentialer, i det fysiske biblioteksrum på tværs af tilsigtede inddelinger i målgrupper. For eksempel voksne, der finder materialer i form af børnebøger, tegneserier mm. i børneafdelingen til sig selv eller unge, der foretrækker at finde materialer i voksenafdelingen. Med brug af teorien om 'affordances' hos Sadler \& Given (2007), kan man her tale om diskrepans mellem opfattede brugspotentialer ('perceived affordances') hos crossover-brugerne og tilsigtede brugspotentialer ('intended affordances') fra bibliotekets side.

\section{Bruger-til-bruger-formidling}

Et yderligere resultat i undersøgelsen er at se brugeren som en vigtig medformidler i det fysiske biblioteksrum - i tråd med den frembrydende Bibliotek 2.0-tankegang (fx Casey \& Savastinuk, 2006; Farkas, 2007) med brugerskabt videndeling i fysiske og digitale biblioteksrum. Eksempelvis fungerer fordelingsreolen, hvor brugerne sætter deres afleverede materialer på plads på Vanløse Bibliotek, som et populært sted for indirekte bruger-til-bruger-formidling og social navigation (Dieberger et al., 2000). I fordelingsreolen går børn og voksne nysgerrigt på opdagelse i hinandens 'adfærdsspor' (hvad har andre lånt), ligesom det er muligt på bogvognene på mange biblioteker. Disse muligheder for serendipitive fund blandt nyafleverede materialer er der ikke på biblioteker med afleveringsrobotter og robot-'madede' skråstillede bogvogne, som findes på fx. HB.

Andre eksempler på bruger-til-bruger-formidling er reolen med læser-til-læser-anbefalede bøger på HB samt skønlitteratur-afdelingen samme sted med faneblade med forskellige 'smileys' og udsagn ('Gab', 'Chok', 'Hulk', mm.), som brugere kan sætte i bøger for at angive, om de kan lide dem eller ej. Efterladte materialer på et bord kan også få brugere til at undersøge, hvad andre brugere har været optaget af. Til gengæld indfangede undersøgelsen ikke eksempler på direkte bruger-til-bruger-formidling, som også findes på bibliotekerne, når brugere udveksler verbale oplysninger og anbefalinger om materialer med hinanden. I denne sammenhæng kan biblioteker signalere, at både direkte og indirekte bruger-til-brugerformidling er noget, man vil understøtte - evt. kun i afgrænsede zoner. For eksempel med reoler, hvor brugere spontant kan sætte materialer frem, der har betydt meget for dem. Oplevelser som de gerne vil dele med andre brugere.

\section{Brugernes kropslighed}

Undersøgelsen viser, hvordan brugeren i det fysiske biblioteksrum kan komme i nærkontakt ansigt-til-ansigt med menneskelige informationsressourcer (personale og andre brugere) og håndgribeligt taktilt med fysiske informationsressourcer. Denne mulighed for direkte nærkontakt må ses som en styrke ved det fysiske bibliotek sammenlignet med det digitale bibliotek, hvor ressourcer kun kan medieres digitalt.

I undersøgelsen kunne vi se, hvordan brugerens kropslighed, motorik og sanseapparat har stor betydning for brugerens adfærd, når materialer skal findes og vælges på biblioteket, hvor den spatiale sans og taktile sans kan bruges til at 'scanne' et rums brugspotentialer, herunder udnytte muligheder for at opdage og relevansvurdere uplanlagte materialer. Eksempelvis udtaler en interviewet mand i 20'erne, at han aldrig slår skønlitteratur op i online-katalogen, men "går rundt og fingererer" ved reolerne. En anden mandlig interviewperson i 30'erne fortæller, hvordan "det betyder meget for mig at røre ved bøgerne". I denne forbindelse er det interessant at pege på et projekt ved Learning Lab, der bl.a. undersøger kroppens betydning for brugernes adfærd i biblioteksrummet (Herskind \& Kjær Jensen, 2005). På lignende vis har museerne fået mere fokus på brugernes kropslighed $\mathrm{i}$ forbindelse med interaktion med fysiske formidlingsrum (fx Ingemann \& Gjedde, 2005).

\section{Bibliotekets samlede brugergrænseflade}

Med henblik på at sætte brugernes informationsadfærd ind i en større kontekst i forhold til bibliotekets forskellige sociale, fysiske og digitale formidlingsrum, blev der i undersøgelsen udviklet en model for biblioteket som en samlet brugergrænseflade bestående af alle kontaktflader, adgangsveje og formidlingsveje mellem bibliotekets menneskelige, fysiske 
og digitale informationsressourcer, som brugere kan interagere med.

Figur 3 viser en bruger, der interagerer med bibliotekets samlede brugergrænseflade, der består af alle kontaktflader (dobbeltpile) og formidlingsveje (enkeltpile, jf. Tabel 4) mellem brugeren og alle menneskelige, fysiske og digitale ressourcer tilgængelige i biblioteket.

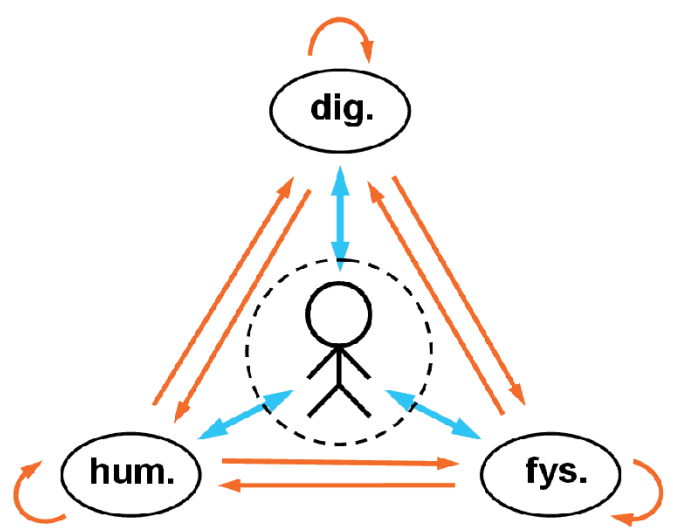

Figur 3. Brugeren, omsluttet (stiplet cirkel) af sin socio-kognitive kontekst (interesser, opgaver, problemer, behov, intentioner mm.), interagerer (dobbeltpile) med bibliotekets samlede brugergranseflade, der består af alle kontaktflader (dobbeltpile) og formidlingsveje (enkeltpile) mellem brugeren og alle menneskelige (hum), fysiske (fys) og digitale (dig) ressourcer tilgcengelige i biblioteket, jf. Tabel 4.
Termen 'brugergrænseflade' bruges normalt om kontaktflader mellem brugere og digitale computere. Men i nyere forskning i menneske-computer-interaktion er man begyndt at se på fysiske rum som udvidede brugergrænseflader, som brugere kan interagere med - og hvis design, indretning og potentialer for brugsoplevelser kan undersøges i forskningsøjemed. For eksempel forskning om såkaldt 'pervasive computing' ('altgennemtrængende' digitale funktioner indlejret i fysiske rum), 'tangible media' ('berørbare medier' jf. Ishii \& Ullmer, 1997) og 'situated computing' (Nielsen, 2006), hvor digitale funktioner tager afsæt i en fysisk og lokalt forankret situation. Danske biblioteker, fx Århus Hovedbibliotek (Thorup, 2007), er begyndt at eksperimentere med sådanne interaktive og oplevelsesorienterede digitale teknologier integreret i fysiske rum.

Pointen ved at tænke 'samlet brugergrænseflade' er, at man så må helhedstænke indretning, sammenhænge, brugspotentialer og brugervenlighed på tværs af alle kontaktflader mellem brugere og alle bibliotekets informationsressourcer - og ikke kun i den digitale grænseflade. Det er her vigtigt at blive mere bevidst om styrker og svagheder i bibliotekets forskellige formidlingsveje, hvor fx ansigt-til-ansigt-kontakt i nogle situationer er at foretrække fremfor for fx chat. For nogle brugere er det vigtigt at røre materialer, for at relevansbedømme dem, som tidligere beskrevet.

En skråhylde eller en hel etage med reoler og formidlingsmøbler kan ses som formidlingsveje ('fys $\rightarrow$ fys' i Figur 3) i bibliotekets samlede brugergrænse-

\begin{tabular}{|c|c|}
\hline Formidlingsveje & Forklaring og eksempler \\
\hline hum $\rightarrow$ hum & $\begin{array}{l}\text { Personale eller bruger henviser til/kommunikerer med anden person } \\
\text { ( } \mathrm{fx} \text { andet personale eller bruger med specialviden) }\end{array}$ \\
\hline hum $\rightarrow$ fys & $\begin{array}{l}\text { Personale eller bruger henviser til fysisk indretning eller materiale } \\
\text { (fx henviser til oversigtskort, DK5-tal, reol, musik-cd) }\end{array}$ \\
\hline hum $\rightarrow$ dig & $\begin{array}{l}\text { Personale eller bruger henviser til digital indretning eller materiale } \\
\text { (fx database, hjemmeside, PDF-fil) }\end{array}$ \\
\hline fys $\rightarrow$ hum & $\begin{array}{l}\text { Fysisk indretning eller materiale henviser til person } \\
\text { (fx plakat 'Book en bibliotekar til personlig vejledning') }\end{array}$ \\
\hline fys $\rightarrow$ fys & $\begin{array}{l}\text { Fysisk indretning/materiale henviser til anden fysisk indretning/materiale } \\
\text { (fx kort over bibliotek, reol-skilte, skråhylde med bogforside) }\end{array}$ \\
\hline fys $\rightarrow$ dig & $\begin{array}{l}\text { Fysisk indretning/materiale henviser til digital indretning/materiale } \\
\text { (fx plakat henviser til webside) }\end{array}$ \\
\hline dig $\rightarrow$ hum & $\begin{array}{l}\text { Digital indretning eller materiale henviser til person } \\
\text { (fx webside henviser til læsegruppe) }\end{array}$ \\
\hline dig $\rightarrow$ fys & $\begin{array}{l}\text { Digital indretning/materiale henviser til fysisk indretning/materiale } \\
\text { (fx webside med kort over fysisk bibliotek, katalogpost med DK5-tal) }\end{array}$ \\
\hline dig $\rightarrow$ dig & $\begin{array}{l}\text { Digital indretning/materiale henviser til anden digital indretning/materiale } \\
(\mathrm{fx} \text { links mellem websider) }\end{array}$ \\
\hline \multicolumn{2}{|c|}{$\begin{array}{c}\text { Tabel 4: Formidlingsveje mellem menneskelige (hum), fysiske (fys) og digitale (dig) } \\
\text { informationsressourcer i bibliotekets samlede brugergrænseflade (Figur } 3 \text { ) }\end{array}$} \\
\hline
\end{tabular}


flade. En bibliotekswebside med læseranbefalinger, der henviser til, hvor bøgerne kan findes i det fysiske bibliotek, er en anden formidlingsvej ('dig $\rightarrow$ fys') i samme samlede brugergrænseflade. Ansigt-til-ansigt-interaktioner mellem brugere og ansatte ('hum $\rightarrow$ hum') er ligeledes formidlingsveje i bibliotekets samlede grænseflade. Den tidligere omtalte indirekte bruger-til-bruger-formidling ('hum $\rightarrow$ hum') er også en vigtig formidlingsvej i den samlede brugergrænseflade. Modellen kan således ses som et bud på, hvordan biblioteket i sin formidlingspolitik kan indtænke Bibliotek 2.0-aspekter omkring brugerinvolvering $\mathrm{i}$ formidlingsveje på tværs af bibliotekets forskellige formidlingsrum.

Formidlingsvejene i Figur 3 og Tabel 4 kan kombineres i lange kæder og sløjfer, der går på tværs af bibliotekets sociale, fysiske og digitale formidlingsrum. En vigtig pointe er, at brugerne kan opdage og genkende en rød tråd i bibliotekets design og lay-out på tværs af disse formidlingsrum ved at formidlingsvejene tydelig spiller sammen og supplerer hinanden.

\section{Serendipitetsfaktorer}

Som det fremgår af tidligere afsnit i denne artikel, er divergent informationsadfærd i form af græsning og uplanlagte serendipitive fund en naturlig del af mange brugeres interaktion med bibliotekets fysiske formidlingsrum.

Van Andel (1994) definerer 'serendipity' som "the art of making an unsought finding", det usøgte fund.
I 1996-udgaven af Informationsordbogen fra Dansk Standard findes en god dansk definition på begrebet serendipitet: "det at man, når man går årvågen gennem verden, făr uventede informationer". Definitionen er god, fordi den indfanger de to essentielle aspekter, der skal være til stede, hvis serendipitet skal opstå. Nemlig et centralt aspekt hos den serendipitetsopdagende person: årvågenhed, dvs. opmærksomhed, der skal være til stede samtidig med et centralt aspekt hos den serendipitetstilbydende omgivelse: noget uventet, noget uplanlagt, noget tilfældigt. Exe Christoffersen (2007) taler her om serendipitet som "evnen til at samarbejde med det tilfældige".

Englænderen Horace Walpole, der skabte ordet 'serendipity' i 1754 (Van Andel, 1994; Merton \& Barber, 2004) ud fra titlen på eventyret om 'The Three Princes of Serendip' (persisk for 'Sri Lanka'), talte om "discoveries by accident and sagacity". Altså et frugtbart møde mellem en indre person-afhængig serendipitetsfaktor på linie med årvågenhed: 'sagacity' (skarpsindighed) - og en ydre person-uafhængig faktor: 'accident' (tilfældighed).

Et af af undersøgelsens to overordnede forskningsspørgsmål vedrørte identificering af ydre faktorer i det fysiske biblioteksrum, der kan påvirke muligheder for serendipitet. Analysen af interviews, observationer og tænke-højt-sessioner mundede ud i en identificering af følgende 10 serendipitetsfaktorer:

De 10 serendipitetsfaktorer i Tabel 5 skal uddybes her:

\begin{tabular}{|c|c|}
\hline Serendipitetsfaktor & Forklaring \\
\hline Uhindret adgang & Brugernes uhindrede, direkte adgang til informationsressourcer \\
\hline Diversitet & $\begin{array}{l}\text { Rig mangfoldighed af emner, materialer, genrer, medier, personer, } \\
\text { aktiviteter og rum }\end{array}$ \\
\hline Eksponering & Nysgerrighedsskabende formidling af informationsressourcer \\
\hline Kontraster & $\begin{array}{l}\text { Iøjnefaldende differentiering med blikfang og variation i formidlingen; } \\
\text { inkl. 'stille'-zoner og eksponeringszoner }\end{array}$ \\
\hline Markører & $\begin{array}{l}\text { Tydelig skiltning, oversigtskort, henvisninger og andre rum-markører kan } \\
\text { trigge brugeres interessesfære }\end{array}$ \\
\hline Uperfekte sprækker & Biblioteket accepterer en vis grad af personale- eller brugerskabt rod \\
\hline Krydskontakter & $\begin{array}{l}\text { Kontaktflader på tværs af emner, materialer, genrer, medier, personer, } \\
\text { aktiviteter og rum }\end{array}$ \\
\hline 'Multi-reachability' & $\begin{array}{l}\text { Mange adgangsveje som brugerne kan vælge gennem biblioteket, hvorved } \\
\text { uplanlagte materialer kan opdages undervejs }\end{array}$ \\
\hline 'Explorability' & Indretning indbyder til udforskning, bevægelse og græsning \\
\hline 'Stopability' & $\begin{array}{l}\text { Indretning indbyder til at standse op, røre ved materialer, fordybe sig, } \\
\text { sætte sig og relevansbedømme materialer, inkl. uplanlagte fund. }\end{array}$ \\
\hline
\end{tabular}


Uhindret adgang. Helt afgørende for mulighederne for serendipitet er brugerens uhindrede direkte adgang til bibliotekets informationsressourcer, hvad enten de er i menneskelig, fysisk eller digital form, jf. Figur 3. Hvis informationsressourcer er gemt bag skranker, i lukkede magasiner, bag kedelige omslag eller i uoverskuelige fortegnelser på websteder mm., vil man begrænse muligheder for serendipitet.

Diversitet. En anden afgørende serendipitetsfaktor er selve den rige mangfoldighed af emner, materialer, genrer, medier, personer, aktiviteter og rum, som brugeren kan gå på opdagelse i på biblioteket. Ikke mange offentligt tilgængelige steder i samfundet indeholder så forskelligartede emner på så forholdsvis lille plads som folkebiblioteker. Denne emne-diversitet, der dækker hele menneskets vidensunivers, er en styrke ved biblioteket og kan serendipitivt trigge brugernes store interesse-diversitet (jf. Figur 1).

Eksponering. Hvordan biblioteket vælger at synliggøre og eksponere denne emne-diversitet er en vigtig serendipitetsfaktor. Biblioteksbrugere kan skynde sig forbi tæt pakkede reoler uden at opdage potentielt spændende men skjulte vidensuniverser lige ved siden af. Nysgerrighedsskabende eksponering kunne være med til at trigge brugeres interessesfærer. Mange interviewpersoner i undersøgelsen fandt uplanlagte materialer, fordi disse var eksponerede, typisk ved at stå med forsiden udad på skråhylder. Som en interviewperson udtrykte det, lagde han altid mærke til "øjenfristelser" og "show off"-bøger. Reoler, skråhylder og andre eksponeringsmøblers placering i forhold til, hvilke retninger brugere typisk kommer gående ad, er også vigtige i denne forbindelse. Lignende aspekter undersøges i shopping-forskning (Underhill, 1999).

Kontraster. Diversitet og eksponering kan ikke stå alene som serendipitetsfaktorer. For at trigge brugernes sanser og skabe variation i sanseindtrykkene er det vigtigt, at eksponeringen rummer kontraster, differentiering, variation og blikfang, fx i form af belysning, farvesætning, lyd, dufte o.l. Men som Underhill (1999) udtrykker det, skal 'visual cacophony' undgås. Kontraster kan også skabes via humoristiske detaljer i udstillinger mm. eller via differentierede zoner i biblioteket i form af 'stille'-zoner (fx i åbne magasiner) og eksponeringszoner.
Markører. Skiltning, henvisninger, oversigtskort (som brugeren også kan have med i hånden) og andre rum-markører er vigtige redskaber, der kan tiltrække brugernes opmærksomhed mod både planlagte og uplanlagte ting. I undersøgelsen var der interview med en far, der havde sin 3-årige dreng med i børneafdelingen på $\mathrm{HB}$, hvor drengen opdagede uplanlagte materialer takket være de farvestrålende emne-ikoner på hylderne.

Uperfekte 'sprckker' og 'smuthuller' i bibliotekets formidling kan ligeledes åbne for uventede fund, hvis biblioteket giver plads til brugerskabte adfærdsspor og accepterer en vis grad af brugerskabt rod, som det ses i de tidligere nævnte eksempler med efterladte materialer på borde og fejlplacerede materialer i reoler.

Krydskontakter. Mulighed for serendipitet kan yderligere opstå ved krydskontakter i form af kontaktflader på tværs af emner, materialer, genrer, medier, personer, aktiviteter og fysiske/digitale rum i biblioteket. For eksempel når genrer blandes i form af jazz-bøger eksponeret sammen med jazz-cd'er, eller forskellige emner, der tilfældigvis havner ved siden af hinanden blandt materialerne, som brugere afleverer i en fordelingsreol. Kombinationen af begrænset fysisk plads og klassifikationssystemets emnediversitet gør, at et par skridt på tværs af en biblioteksgang emnemæssigt kan føre brugeren langt væk. Serendipitet kan således stimuleres når emnemæssig bredde kombineres med fysisk tæthed.

'Multi-reachability'. Gangbaner gennem det fysiske bibliotek kan muliggøre mange forskellige ruter og adgangsveje, som brugerne kan vælge gennem biblioteket. På lignende vis kan hypertekst-links muliggøre forskellige ruter gennem digitale biblioteksrum på bibliotekets websted eller katalog. Disse mangfoldige 'affordances', brugspotentialer, til at nå fra et punkt til et andet i fysiske eller digitale informationsrum kaldes her 'multi-reachability'. 'Multi-reachability' er relateret til bevægelsesfrihed og muligheder for serendipitet. Jo flere forskellige ruter brugeren kan vælge at bevæge sig ad gennem fysiske eller digitale informationsrum, desto flere forskellige informationsressourcer og emner kan brugeren blive eksponeret for, og desto flere chancer er der for at få trigget 'latente' interesser. 
'Explorability' er relateret til 'multi-reachability'. Begrebet stammer fra forskning i menneske-computer-interaktion om brugsoplevelse (fx Constantine \& Lockwood, 2002). I nærværende undersøgelse bruges begrebet i forhold til, hvor indbydende, nysgerrighedsskabende og udforskningsmotiverende bibliotekets fysiske eller digitale indretning er $\mathrm{mhp}$. at invitere brugere til at bevæge sig gennem biblioteket og udforske dets brugspotentialer inkl. dem der findes i bibliotekets 'sideveje'.

'Stopability' er en term brugt i nærværende undersøgelse til at skabe komplementaritet i relation til 'explorability'. Begrebet dækker, i hvilken grad bibliotekets indretning indbyder til, at brugeren får lyst til at standse op, røre ved materialerne, måske sætte sig og relevansbedømme materialer, inklusive uplanlagte fund. I det fysiske rum handler 'stopability' fx om siddemuligheder tæt på materialerne og om afsætningsplads på hylder, borde, mm., så brugere kan standse op, sætte ting fra sig og have hænderne fri til røre og undersøge nyfundne materialer.

De 10 serendipitetsfaktorer er ikke udtømmende, da der kan være yderligere faktorer, som en mere omfattende undersøgelse ville kunne identificere. I en sådan undersøgelse kunne det være interessant at se, hvordan de identificerede serendipitetsfaktorer kunne relateres til lignende faktorer i shoppingsteder, museer og andre fysiske oplevelsesmiljøer. En undersøgelse af digitale informationsrum eller førnævnte fysisk-digitale rum, dvs. fysiske rum med indlejrede digitale funktioner, må antages at kunne identificere yderligere serendipitetsfaktorer. De ovenstående 10 faktorer kan dog alle omsættes til digitale og fysiskdigitale rum.

De 10 faktorer er ikke gensidigt udelukkende, da de kan overlappe hinanden. For eksempel kan en markør som et skilt også fungere som kontrast. Uperfekte 'sprækker' som efterladte materialer på et bord kan fungere som krydskontakter, hvis materialerne er efterladt af flere brugere med forskellige interesseområder.

For alle serendipitetsfaktorer gælder, at der skal være en balance mellem dem, så der ikke bliver 'overkill', hvilket kan have modsat virkning hos brugerne, idet de kan lukke af for serendipitive fund.
Det skal bemærkes, at ovenstående muligheder for serendipitet og divergent, eksplorativ brugeradfærd ikke behøver udelukke muligheder for konvergent, målrettet adfærd. Uhindret adgang, eksponering, markører, 'explorability' og 'stopability' er eksempelvis alle faktorer, der også kan hjælpe den målrettede bruger med at finde planlagte materialer.

Det er vigtigt at understrege, at man ikke kan indrette et biblioteksrum, så brugere med garanti oplever serendipitet. Man kan altså ikke planlægge det uplanlagte, men man kan skabe bredest mulige rammer og 'affordances', dvs. brugspotentialer der kan stimulere og understøtte - og i det mindste ikke modvirke muligheder for serendipitet. Som nævnt ovenfor, skal der være et samspil mellem indre og ydre serendipitetsfaktorer, mellem serendipitetsopdagende brugere og serendipitetstilbydende informationsrum. Eller udtrykt med tidligere nævnte 'affordances'-termer: en overensstemmelse mellem 'perceived affordances' hos brugeren på den ene side og 'intended/unintended affordances' i biblioteket på den anden side.

De 10 oplistede serendipitetsfaktorer er alle ydre faktorer ved informationsrummet. I undersøgelsen var der ikke fokus på indre, personafhængige faktorer, såsom nysgerrighed, tid, energi, humør, personlighed, erfaring, genkendelse, intentioner o.l., der kan gøre brugere modtagelige for serendipitive fund. I en fremtidig undersøgelse ville det være interessant at inddrage Erdelez' (1997) forskning om 'information encountering' og 'super encounters', der bl.a. indbefatter forskellige grader af serendipitetsmodtagelighed hos brugere.

\section{Konklusion og perspektivering}

Artiklen startede med tre spørgsmål, der har gennemsyret den seneste biblioteksdebat:

- Hvad er et bibliotek? Hvad kan et bibliotek? Hvad skal et bibliotek?

Disse tre indbyrdes forbundne spørgsmål har også ligget implicit i præsentationen i artiklen, som belyser, hvordan brugere finder materialer på folkebiblioteker og hvilke faktorer, der kan stimulere serendipitet i fysiske biblioteksrum.

På spørgsmålet 'hvad er et bibliotek?' er artiklen kommet med et bud, nemlig at biblioteket er en sam- 
let brugergrcenseflade. Ved at tænke biblioteket som en samlet brugergrænseflade, bliver det oplagt at helhedstænke design, indretning, brugervenlighed og oplevelsesmuligheder på tværs af alle kontaktflader og formidlingsveje mellem brugere og bibliotekets menneskelige, fysiske og digitale informationsressourcer. Biblioteket kan derved ses som en fællesmængde af sociale, fysiske og digitale formidlingsrum, hvis hovedfunktion er at fungere som platforme for formidling af viden og kultur til glæde for brugerne.

På spørgsmålet 'hvad kan et bibliotek?' er svaret, at man kan se biblioteksmedarbejdere som designere af 'mulighedsrum' for forskellige typer adfærd, brug og oplevelser - eller 'affordance spaces', for at blive i artiklens brug af begrebet 'affordances', dvs. brugspotentialer og handlemuligheder. Det daglige arbejde i biblioteket består i at designe mulighedsrum i form af formidlingsrum og formidlingsveje, der skaber brugspotentialer for brugerne. Brugspotentialer som brugerne kan udforske og udnytte - og måske også udvide, i tråd med den frembrydende Bibliotek 2.0-tankegang, hvor brugerne bliver medskabere af bibliotekets formidlingsrum. I denne forbindelse kan biblioteket med fordel åbne op for forskellige faggrupper, der kan bidrage med kompetencer inden for brugerinvolvering, formidling, indretning, design, udstillinger, $\mathrm{mm}$.

Undersøgelsens afdækning af brugernes komplekse hverdagspraksis i relation til at finde materialer på biblioteket viser, at ovennævnte mulighedsrum skal imødekomme to overordnede behov hos brugerne. På den ene side skal biblioteket skabe overblik og navigationsmuligheder i den samlede brugergrænseflade, der gør det nemmere for brugere med konvergent informationsadfærd at finde det planlagte. Dvs. biblioteket skal skabe brugspotentialer i bibliotekets forskellige formidlingsrum, der hjælper brugere med at finde, hvad de bevidst leder efter.

På den anden side skal biblioteket også stimulere nysgerrighed og serendipitet i den samlede brugergrænseflade, der vil gøre det nemmere for brugere med divergent informationsadfærd at finde det uplanlagte. Dvs. biblioteket skal skabe brugspotentialer i bibliotekets forskellige formidlingsrum, der hjælper brugere med at finde, hvad de ikke bevidst leder efter. Undersøgelsens identificering af 10 serendipitetsfaktorer vil kunne bruges af biblioteker til mere bevidst at skabe brugspotentialer for serendipitet $\mathrm{i}$ bibliotekets formidlingsrum.

På det sidste spørgsmål 'hvad skal et bibliotek?' skal det her anbefales, at bibliotekerne formulerer formidlingspolitikker, der i hverdagssprog sætter ord på, hvordan man i bibliotekets forskellige afdelinger og teams ønsker at formidle menneskelige, fysiske og digitale ressourcer. Formidlingspolitikken skal konkretisere, hvilke formidlingstiltag man vil sætte i værk og hvilke konkrete metoder og formidlingsveje man vil bruge og udbygge, fx for at understøtte konvergent og divergent informationsadfærd. Her er det vigtigt at lave løbende evalueringer af formidlingspolitikken for at få svar på, hvad der fungerede godt, og hvad der kan forbedres. Endelig kan en reflekteret formidlingspolitik være et redskab til at udvikle helhedstænkning i formidlingsvejene på tværs af bibliotekets samlede brugergrænseflade.

\section{Anerkendelse}

Undersøgelsen blev støttet med midler fra Kulturministeriets Forskningspulje, KuM j.nr. TAKT 2005059 og 2006-094. Tak til de to anonyme reviewere for gode konstruktive kommentarer og ændringsforslag.

\section{Noter}

1. Begrebet serendipitet uddybes i afsnittet 'Serendipitetsfaktorer'.

2. Undersøgelsen er også beskrevet i Björneborn (2005) og Björneborn \& Brendstrup (2008).

3. Denne skelnen mellem 'information recovery' (genfinding) og 'information discovery' (opdagelse) er hentet hos Garfield (1986), der bruger termerne til at diskutere komplementære aspekter ved søgning i citationsdatabaser. Garfield (2004) omtaler i den forbindelse, hvordan citationsdatabaser bl.a. kan muliggøre 'systematic serendipity'.

4. Winding (2007a; 2007b) bruger betegnelserne 'målrettede lånere', 'tryghedslånere', 'surrogatlånere', 'supplementslånere', 'impulslånere' og 'potentielle lånere'.

5. Björneborn (2006) bruger begrebet 'reachability structures' til at undersøge, hvordan man kan nå 
('reach') fra et punkt til et andet punkt i hypertekststrukturer på tværs af WWW.

\section{Referencer}

Andersen, C (2007). Bøgerne skal have modstand [interview med Pernille Schaltz]. Politiken, 27.12.2007

Bates, MJ (1989). The design of browsing and berrypicking techniques for the online search interface. Online Review, 13(5): 407-424.

Björneborn, L (2005). Serendipitet på det fysiske bibliotek. Bibliotekspressen, nr. 16, s. 18-19.

Björneborn, L (2006). 'Mini small worlds' of shortest link paths crossing domain boundaries in an academic Web space. Scientometrics, 68(3): 395-414.

Björneborn, L \& Brendstrup, E (2008). Brugeradfærd og serendipitet, Bibliotekspressen, nr. 1, s. 6-7.

Buschman, JE \& Leckie, GJ (red.)(2007). The Library as Place : History, Community and Culture. Westport, Conn.: Libraries Unlimited.

Casey, ME \& Savastinuk, LC (2006). Library 2.0 : service for the next-generation library. Library Journal, 1.9.2006. Lokaliseret 30.5.2008: http://www. libraryjournal.com/article/CA6365200.html

Chang, S \& Rice, RE (1993). Browsing : a multidimensional framework. Annual Review of Information Science and Technology, 28: 231-276.

Constantine, LL \& Lockwood, LAD (2002). Instructive interaction: making innovative interfaces selfteaching. User Experience, 1(3): 14-19.

Dieberger, A, Dourish, P, Höök, K, Resnick, P \& Wexelblatt, A (2000). Social navigation: techniques for building more usable systems. Interactions, 7(6): $36-45$.

Erdelez, S (1997). Information encountering: a conceptual framework for accidental information discovery. s. 412-421. In: Vakkari, Savolainen \& Dervin (red.). Information seeking in context: proceedings of an international conference on research in information needs, seeking and use in different contexts. 14-
16 August, 1996, Tampere, Finland. London: Taylor Graham.

Exe Christoffersen, E (2007). Kunsten at snuble : Om serendipitet og benspænd. Peripeti : tidsskrift for dramaturgiske studier : Scernummer 2007 : Serendipitet. s. 15-33. Lokaliseret 30.5.2008: http://www. dramaturgi.au.dk/forskning/publikationer/peripeti/serendipitet

Farkas, MG (2007). Social Software in Libraries : Building Collaboration, Communication, and Community Online. Medford, N.J.: Information Today.

Ford, N (1999). Information retrieval and creativity: towards support for the original thinker. Journal of Documentation, 55(5): 528-542.

Foster, A \& Ford, N (2003). Serendipity and information seeking: an empirical study. Journal of Documentation, 59(3): 321-340.

Garfield, E (1986). The metaphor-science connection. Current Comments, 42(Oct. 20): 3-10.

Garfield, E (2004). Systematic serendipity: finding the undiscovered answers to science questions. Presentation at the Medical Ignorance Collaboratory, University of Arizona, Tucson. Lokaliseret 30.5.2008: http://www.garfield.library.upenn.edu/papers/az072004.pdf

Given, LM \& Leckie, GJ (2003). 'Sweeping' the library: mapping the social activity space of the public library. Library \& Information Science Research, 25(4): 365-385.

Goodall, DL (1989). Browsing in public libraries. Loughborough University of Technology.

Herskind, M \& Kjær Jensen, S (2005). Vi spørger kroppen til råds. Learning Lab Denmark Quarterly, nr. 4, 2005, s. 8.

Ingemann, B \& Gjedde, L (2005). Kroppen på museum : Eksperimentel undersøgelse af interaktivitet mellem brugere og museale genstande og rum. s. 165-228. In: Ingemann, B. \& Hejlskov Larsen, A. (red.) (2005). Ny dansk museologi. Århus Universitetsforlag. 
Ingwersen, P (1992). Information retrieval interaction. London: Taylor Graham.

Ishii, H \& Ullmer, B (1997). Tangible bits: towards seamless interfaces between people, bits and atoms. s. 234-241. Proceedings of CHI 97. Atlanta: ACM Press.

KKB (2004). Brugerundersøgelse på Bibliotekerne 2004. Københavns Kommunes Biblioteker.

Leckie, GJ \& Given, LM (2005). Understanding information seeking: the public library context. Advances in Librarianship, 29: 1-72.

Lushington, N (2002). Libraries designed for users : a 21st century guide. New York: Neal-Schuman.

Merton, RK \& Barber, EG (2004). The travels and adventures of serendipity: a study in historical semantics and the sociology of science. Princeton, N.J.: Princeton University Press.

Niegaard, H et al. (red.)(2008). Biblioteksrummet : Inspiration til bygning og indretning. Danmarks Biblioteksforening.

Nielsen, R (2006). Nye anvendelser af interaktive teknologier i rumligt design : Situated Computing: afscet $i$ rum, sted \& tid. Ph.d.-afhandling. Centre for Advanced Visualization and Interaction, Institute of Information and Media Studies, University of Aarhus. Lokaliseret 30.5.2008: http://www.daimi.au.dk/ $\sim$ nrune/web/texter/Afhandling_RN.pdf

Norman, D (1999). Affordance, conventions, and design. Interactions, 6(3): 38-42.

Pors, NO (1994). Tilgaengelighed og grcesning : Om bibliotekernes brugere, materialer og servicekvalitet. Danmarks Biblioteksforenings Forlag.

Sadler, E \& Given, LM (2007). Affordance theory: a framework for graduate students' information behavior. Journal of Documentation, 63(1): 115-141.

Spink, A (2004). Multitasking information behavior and information task switching : an exploratory study. Journal of Documentation, 60(4): 336-351.
Thorup, W (2007). Forvandlingsrum - En rapport om formidlingsformer $i$ det fysiske rum. Århus Kommunes Biblioteker. Lokaliseret 30.5.2008: http:// www.aakb.dk/graphics/user/HB/projekter/Forvandlingsrum/Evaluering/forvandlingsrum.pdf

Underhill, P (1999). Why We Buy: The Science of Shopping. New York: Simon \& Schuster.

Van Andel, P (1994). Anatomy of the unsought finding : serendipity: origin, history, domains, traditions, appearances, patterns and programmability. British Journal for the Philosophy of Science, 45(2): 631-648.

Winding, L (2007a). Brugerne i DUS - en adfcerdsbaseret brugerundersøgelse med fokus på folkebibliotekets samlede ressourcer. Erhvervsrelateret projekt. Danmarks Biblioteksskole

Winding, L (2007b). Ny undersøgelse om brugeradfærd: Lånerne er begejstrede for det fysiske bibliotek. Bibliotekspressen, nr. 10, s. 26-29.

\section{Bilag 1: Interviewguide}

I interviews med brugere på de to undersøgte biblioteker blev følgende interviewguide brugt:

1. Antal lånte materialer (samt beskrivelse af dem)

2. Formål med besøget og de lånte materialer (eget/ andres brug, fritid, faglig brug $\mathrm{mm}$.)

3. Hvilke af de lånte materialer var planlagt at låne?

4. Hvordan er materialerne fundet? (net, katalog, bibliotekar, oversigtskort, græsning, tilfældighed, $\mathrm{mm}$.)

5. Er der noget i bibliotekets indretning, der har medført brugbare fund?

6. Er det lånte udtryk for dit normale forbrug eller låner du anderledes andre gange?

7. Er det hændt at du har fundet noget brugbart uden at lede målrettet efter det? Hvis ja, hvordan er det sket (fysisk, digitalt)?

8. Oplevet forskel mellem at græsse i det fysiske rum og i biblioteksdatabasen

9. Ris/ros til biblioteket

10. Alder, Køn, Etnicitet, Erhvervsmæssig status.

11. Hvor ofte besøger du dette bibliotek?

12. Besøger du andre biblioteker? Hvor ofte og med hvilket formål? 